\title{
Motivasi Siswa dalam Pembelajaran Pjok di Masa Pandemi Covid- 19 pada Siswa SMPN 2 Tembelang Tahun Ajaran 2020/2021
}

\author{
Umi Ayu', Arsika Yunarta ${ }^{1}$ \\ ${ }^{1}$ Pendidikan Jasmani, Sekolah Tinggi Keguruan dan IImu Pendidikan PGRI Jombang \\ Email: ${ }^{1}$ Ayuzulyanti@gmail.com, ${ }^{2}$ arsikayunarta.stkipjb@gmail.com
}

\begin{abstract}
Abstrak
Motivasi merupakan salah satu faktor penting yang mempengaruhi belajar dan Hasil belajar. Seseorang yang memiliki motivasi mempunyai kecenderungan untuk mencurahkan segala kemampuannya untuk mendapatkan hasil belajar yang optimal sesuai dengan tujuan yang diharapkan. Semakin tinggi motivasi yang dimiliki siswa akan mendorong siswa belajar lebih giat lagi dan frekuensi belajarnya menjadi semakin meningkat, sehingga hasil belajarnyapun meningkat. Permasalahan yang dikaji dalam penelitian ini adalah motivasi siswa dalam pembelajaran PJOK dimasa pandemic COVD-19 dan pengaruh motivasi belajar terhadap hasil belajar siswa. Penelitian ini bertujuan untuk mengetahui bagaimana motivasi siswa dalam pembelajaran PJOK dimasa pandemic COVD-19 pada siswa SMPN 2 Tembelang dan untuk mengetahui seberapa besar pengaruh motivasi belajar terhadap hasil belajar siswa. Metode yang digunakan adalah metode kualitatif dengan pendekatan survey Populasi penelitian ini adalah siswa kelas VIII SMPN 2 Tembelang Tahun ajaran 2020/2021 sebanyak 128 siswa. Pengambilan sampel melalui teknik Simple Random Sampling. Metode pengumpulan data yang digunakan dalam penelitian ini adalah angket (kuesioner), dokumentasi dan observasi. Hasil penelitian menunjukkan bahwa motivasi belajar pada siswa SMPN 2 Tembelang dalam kategori tinggi. Berdasarkan hasil penelitian di atas, dapat diambil kesimpulan bahwa ada pengaruh yang signifikan motivasi siswa pembelajaran PJOK dimasa pandemi COVID-19 pada siswa SMPN 2 Tembelang.
\end{abstract}

Kata kunci: Survei, Motivasi belajar, Pembelajaran Daring.

\begin{abstract}
Motivation is one of the important factors that affect learning and learning outcomes. Someone who has motivation has a tendency to devote all his abilities to get optimal learning outcomes in accordance with the expected goals. The higher the motivation of students will encourage students to study harder and the frequency of learning will increase, so that learning outcomes increase. The problems studied in this study are: How is the motivation of students in learning PJOK during the COVD-19 pandemic and how much influence learning motivation has on student learning outcomes. This study aims to determine how students' motivation in learning PJOK during the COVD-19 pandemic in SMPN 2 Tembelang students and to find out how much influence learning motivation has on student learning outcomes. the method used is qualitative with a survey approach. The population of this study was 128 students of class VIII SMPN 2 Tembelang for the 2020/2021 academic year. Sampling was done through Simple Random Sampling technique. The data collection method used in this research is a questionnaire (questionnaire), documentation and observation. The results showed that the learning motivation of the students of SMPN 2 Tembelang was in the high category. Based on the results of the research above, it can be concluded that there is a significant influence on the motivation of PJOK learning students during the COVID-19 pandemic on students of SMPN 2 Tembelang..
\end{abstract}

Keywords : Survey, learning motivation, online learning 


\section{PENDAHULUAN}

Pendidikan dan pengajaran adalah suatu proses yang sadar tujuan. Tujuan dapat diartikan sebagai suatu usaha untuk memberikan rumusan hasil yang diharapkan siswa setelah melaksanakan pengalaman belajar (Sadirman, 2004). Dalam pendidikan terdapat proses pembelajaran yang dilakukan secara rutin dan terstruktur, yang biasa disebut dengan kegiatan belajar mengajar. pendidikan adalah kegiatan yang sangat penting bagi seseorang untuk bekal mempersiapkan kehidupan yang mendatang. Menurut UU Republik Indonesia Nomor 20 Tahun 2003 Tentang Sistem Pendidikan Nasional, Bab II Pasal 3 menyebuytkan bahwa : "Pendidikan nasional berfungsi membentuk watak serta peradaban bangsa yang bermartabat dalam rangka mencerdaskan kehidupan bangsa, bertujuan untuk mengembangkan potensi siswa agar menjadi manusia yang beriman dan bertakwa kepada Tuhan Yang Maha Esa, berakhlak mulia, sehat, berilmu, cakap, kreatif, mandiri, dan menjadi warga negara yang demokratis serta bertanggung jawab".

Permasalahan di dalam pendidikan tersebut merupakan prioritas utama yang harus dipecahkan, salah satunya menyangkut tentang masalah kualitas pendidikan. Kualitas pendidikan saat ini tengah mengalami tantangan sebagai dampak mewabahnya virus Covid19. Covid-19 menjadi pandemi global yang penyebarannya begitu menghawatirkan. Akibatnya pemerintah harus bekerja sama untuk menekan laju penyebaran virus Covid-19 dengan mengeluarkan kebijakan agar seluruh warga masyarakat untuk melakukan social distancing atau menjaga jarak. Sehingga dengan adanya kebijakan tersebut seluruh aktivitas masyarakat yang dulu dilakukan di luar rumah dengan berkumpul dan berkelompok, kini harus diberhentikan sejenak dan diganti dengan beraktivitas di rumah masing-masing. Karena kodisi yang seperti ini pembelajaran diharusan untuk dilakukan di rumah masing-masing, Sebenarnya pembelajaran daring ini bukan hal baru bagi Indonesia, model pembelajaran ini telah dikembangkan sejak tahun 2013 sebagai alternatif pembelajaran, artinya sebelum adanya wabah virus ini, Indonesia telah mengaplikasikan metode tersebut. Tetapi tidak semua lembaga yang mengaplikasikan, terutama sekolahsekolah yang berada di pedesaan. Dengan adanya wabah virus ini, membuat dan mengharuskan seluruh sekolah, perguruan tinggi dan lembaga pendidikan lainnya, menggunakan metode pembelajaran daring tanpa terkecuali, dengan tujuan agar proses pembelajaran tetap berjalan meskipun harus dilakukan di rumah masing-masing.

Keadaan ini tentu saja memberikan dampak pada kualitas pembelajaran, siswa dan guru yang sebelumnya berinteraksi secara langsung dalam ruang kelas dan menggunakan sarana prasanan secara lengkap tetapi sekarang harus berinteraksi dalam ruang virtual yang terbatas. guru dituntut memberikan pengajaran yang baik, menciptakan suasana yang kondusif untuk belajar dan secara kreatif dan inovatif menggunakan media belajar yang menarik agar siswa dapat memahami materi pembelajaran dan tujuan pembelajaran dapat tercapai.

Selain itu, motivasi belajar siswa juga berpengaruh dalam keberhasilan pembelajaran. Motivasi belajar yang dimiliki siswa dalam setiap kegiatan pembelajaran sangat berperan untuk meningkatkan prestasi siswa dalam mata pelajaran tertentu (Nazhar, 2004:11). Oleh karena itu motivasi belajar sangat penting untuk dimiliki oleh setiap siswa, baik motivasi intrinsik maupun ekstrinsik.

Iklim belajar yang diciptakan pembelajaran daring turut mempengaruhi motivasi belajar siswa, jika dalam pembelajaran luring guru mampu menciptakan suasana kelas kondusif untuk menjaga motivasi belajar siswa agar pembelajaran dapat tercapai karena iklim kelas memiliki pengaruh yang signifikan dengan motivasi belajar. Namun kondisi pembelajaran daring menyebabkan guru kesulitan untuk mengontrol dan menjaga iklim belajar karena terbatas dalam ruang virtual. Kondisi ini menyebabkan motivasi belajar siswa dapat menurun bahkan mempengaruhi hasil belajar siswa.

Motivasi merupakan salah satu faktor penting yang mempengaruhi belajar dan Hasil belajar. Seseorang yang memiliki motivasi mempunyai kecenderungan untuk mencurahkan segala kemampuannya untuk mendapatkan hasil belajar yang optimal sesuai dengan tujuan yang diharapkan. Semakin tinggi motivasi yang dimiliki siswa akan mendorong siswa belajar 
lebih giat lagi dan frekuensi belajarnya menjadi semakin meningkat, sehingga hasil belajarnyapun meningkat. Akan tetapi, kuat dan lemahnya motivasi setiap orang berbeda, hal itu dipengaruhi oleh faktor cita-cita atau aspirasi, kemampuan belajar, kondisi siswa, kondisi lingkungan siswa, unsur-unsur dinamis dalam belajar dan upaya guru dalam membelajarkan siswa. Namun, kebenaran argument ini perlu dibuktikan melalui kegiatan penelitian agar diperoleh jawaban yang akurat.

Penelitian ini bertujuan untuk mencari titik permasalahan yang menjadi kendala, faktor-faktornya serta dampak yang ditimbulkan. Manfaat dari penelitian ini adalah untuk memperkaya khazanah keilmuan dan literasi di bidang pendidikan khususnya pada masa pandemi ini. Dan juga sebagai perpanjangan saran kepada pihak-pihak akademisi dan dinas pendidikan yang masih terus berupaya memperbaiki sistem pendidikan di Indonesia khususnya. Maka dari itu, peneliti tertarik untuk menindaklanjuti permasalahan tersebut dengan tujuan untuk untuk mengetahui motivasi belajar siswa SMPN 2 TEMBELANG selama pembelajaran daring di tengah situasi pandemi Covid-19.

\section{Motivasi}

Belajar Motivasi merupakan faktor penggerak maupun dorongan yang dapat memicu timbulnya rasa semangat dan juga mampu merubah tingkah laku manusia atau individu untuk menuju pada hal yang lebih baik untuk dirinya sendiri. Sardiman (1990) mendefinisikan "motivasi sebagai keseluruhan daya penggerak di dalam diri siswa yang menimbulkan kegiatan belajar, yang menjamin kelangsungan dari kegiatan belajar dan yang memberikan arah pada kegiatan belajar, sehingga tujuan yang dikehendaki oleh subjek belajar itu dapat tercapai". Motivasi adalah perubahan dalam diri atau pribadi seseorang yang ditandai dengan timbulnya perasaan dan reaksi untuk mencapai tujuan. Motivasi dapat ditinjau dari dua sifat, yaitu motivasi intrinsik dan motivasi ekstrinsik. Motivasi intrinsik adalah keinginan bertindak yang disebabkan pendorong dari dalam individu, sedangkan motivasi ekstrinsik adalah motivasi yang keberadaannya karena pengaruh dari luar individu. Tingkah laku yang terjadi dipengaruhi oleh lingkungan. Winkel (1983: 270) mendefinisikan bahwa "Motivasi belajar adalah keseluruhan daya penggerak di dalam diri siswa yang menimbulkan kegiatan serta memberi arah pada kegiatan belajar". Dari berbagai pengertian di atas dapat diambil pengertian bahwa motivasi belajar adalah suatu dorongan atau daya penggerak dari dalam diri individu yang memberikan arah dan semangat pada kegiatan belajar, sehingga dapat mencapai tujuan yang dikehendaki. Jadi peran motivasi bagi siswa dalam belajar sangat penting. Dengan adanya motivasi akan meningkatkan, memperkuat dan mengarahkan proses belajarnya, sehingga akan diperoleh keefektifan dalam belajar.

\section{Fungsi Motivasi Belajar}

Motivasi memiliki fungsi bagi seseorang, karena motivasi dapat menjadikan seseorang mengalami perubahan ke arah yang lebih baik. Keberhasilan proses belajar mengajar juga dipengaruhi oleh motivasi belajar siswa. Dua fungsi motivasi dalam proses pembelajaran yang dikemukakan oleh Sanjaya (2010:251-252) yaitu :

a. Mendorong siswa untuk beraktivitas

Perilaku setiap orang disebabkan karena dorongan yang muncul dari dalam yang disebut dengan motivasi. Besar kecilnya semangat seseorang untuk bekerja sangat ditentukan oleh basar kecilnya motivasi orang tersebut. Semangat siswa dalam menyelesaikan tugas yang diberikan oleh guru tepat waktu dan ingin mendapatkan nilai yang baik karena siswa memiliki otivasi yang tinggi untuk belajar.

b. Sebagai pengarah

Tingkah laku yang ditunjukkan setiap individu pada dasranya diarahkan untuk memenuhi kebutuhannya atau untuk mencapai tujuan yang telah ditentukan. Dengan demikian motivasi berfungsi sebagai pendorong usaha dan pencapaian prestasi.

Adanya motivasi yang baik dalam belajar menunjukkan hasil yang baik.. Selanjutnya B. Uno (2008: 17) menjelaskan bahwa fungsi motivasi dalam belajar adalah sebagai berikut: Mendorong manusia untuk melakukan suatu aktivitas yang didasarkan atas pemenuhan 
kebutuhan, menentukan arah tujuan yang hendak dicapai, menentukan perbuatan yang harus dilakukan. menurut Winarsih (2009:111) ada tiga fungsi motivasi yaitu:

1. Mendorong manusia untuk berbuat, jadi sebagai penggerak atau motor yang melepaskan energi. Motivasi dalam hal ini merupakan motor penggerak dari setiap kegiatan yang dilakukan.

2. Menentukan arah perbuatan kearah yang ingin dicapai. Dengan demikian motivasi dapat memberikan arah dan kegiatan yang harus dikerjakan sesuai dengan rumusan tujuannya.

3. Menyeleksi perbuatan, yakni menentukan perbuatan-perbuatan apa yang harus dikerjakan guna mencapai tujuan,

Jadi adanya motivasi akan memberikan dorongan, arah dan perbuatan yang akan dilakukan dalam upaya mencapai tujuan yang telah dirumuskan sebelumnya.

Berdasarkan pendapat di atas, fungsi motivasi dalam belajar antara lain adalah untuk mendorong, menggerakan dan mengarahkan aktivitas-aktivitas siswa dalam belajar sehingga dapat mencapai hasil yang maksimal. Dengan hal tersebut seseorang melakukan suatu usaha yang sungguh-sungguh karena adanya motivasi yang baik.

\section{Ciri-Ciri Motivasi Belajar}

Orang termotivasi dapat dilihat dari ciri-ciri yang ada pada diri orang tersebut. Berikut ini akan diuraikan beberapa pendapat tentang ciri-ciri dalam motivasi belajar siswa, Sardiman (2011: 83) mengemukakan ciri-ciri orang yang bermotivasi adalah sebagai berikut:

1. Tekun menghadapi tugas

2. Ulet menghadapi kesulitan

3. Menunjukan minat terhadap bermacam-macam masalah

4. Lebih senang bekerja mandiri

5. Cepat bosan pada tugas-tugas rutin

6. Dapat mempertahankan pendapatnya

7. Tidak mudah melepaskan hal yang diyakini itu

8. Senang memecahkan masalah soal-soal berikut:

Ciri-ciri motivasi belajar menurut Uno (2008: 23) dapat diklasifikasikan sebagai

1. Adanya hasrat dan keinginan berhasil

2. Adanya dorongan dan kebutuhan dalam belajar

3. Adanya harapan dan cita-cita masa depan

4. Adanya penghargaan dalam belajar

5. Adanya kegiatan yang menarik dalam belajar

6. Adanya lingkungan belajar yang kondusif

Dari beberapa ciri-ciri motivasi menurut para ahli di atas dapat disimpulkan bahwa adanya motivasi yang baik dalam belajar akan menunjukan hasil yang baik. Dengan kata lain bahwa dengan adanya usaha yang tekun, menunjukan ketertarikan, senang mengikuti pelajaran, selalu memperhatikan pelajaran, semangat dalam mengikuti pelajaran, mengajukan pertanyaan, berusaha mempertahankan pendapat, senang memecahkan masalah soal-soal, maka pembelajaran akan berhasil dan seseorang yang belajar itu dapat mencapai prestasi yang baik.

\section{Macam-Macam Motivasi Belajar}

Pada dasarnya siswa memiliki bermacam-macam motivasi dalam belajar. Seperti yang dikemukakan Sugihartono dkk (2007: 78) membedakan macam-macam motivasi tersebut menjadi 4 golongan, yaitu:

1. Motivasi Instrumental Pada golongan ini, siswa belajar karena didorong oleh adanya hadiah atau untuk menghindari hukuman.

2. Motivasi Sosial Motivasi sosial berarti bahwa siswa belajar disebabkan adanya dorongan untuk penyelenggaraan tugas, dalam hal ini keterlibatan siswa pada tugas menonjol.

3. Motivasi Berprestasi Jenis motivasi ini, siswa belajar untuk meraih prestasi atau keberhasilan yang telah ditetapkannya. 
4. Motivasi Instrinsik Motivasi siswa belajar karena keinginannya sendiri.

Dari keempat jenis motivasi di atas sebaiknya dimiliki secara keseluruhan oleh siswa. Namun yang terpenting adalah motivasi/ keinginan yang muncul dari dalam dirinya untuk belajar, sehingga dengan adanya unsur kesengajaan dalam belajar pasti hasilnya akan lebih baik.

\section{Faktor-Faktor yang Mempengaruhi Motivasi Belajar}

Menurut B. Uno (2011: 23) motivasi belajar dapat timbul karena faktor intrinsik dan ekstrinsik. Faktor intrinsik yang mempengaruhi motivasi belajar yaitu "pertama, hasrat dan keinginan berhasil dan dorongan kebutuhan belajar, dan kedua, harapan akan cita- cita". Faktor ekstrinsik yang mempengaruhi motivasi belajar meliputi "pertama adanya penghargaan, kedua, lingkungan belajar yang kondusif, dan ketiga, kegiatan belajar yang menarik".

Jadi untuk meraih motivasi belajar yang tinggi bagi siswa, harus diperhatikan faktor yang mempengaruhinya baik intrinsik maupun ekstrinsik. Siswa harus menyadari dengan sengaja untuk melakukan kegiatan dan kebutuhan belajar untuk meraih tujuan (cita-cita yang hendak dicapai). Faktor ekstrinsik harus disertai penghargaan (pujian) jika siswa berprestasi, diperlukan lingkungan belajar yang kondusif dan kegiatan belajar yang menarik. Dalam hal ini peran orang tua diperlukan untuk menciptakan suasana yang kondusif dan membantu anaknya dalam belajar.

\section{Cara Menumbuhkan Motivasi Belajar}

Sardiman A.M (2011: 92-95) mengungkapkan ada beberapa bentuk dan cara untuk menumbuhkan motivasi dalam kegiatan belajar di sekolah, yaitu:

1. Memberi Angka Angka ini berkaitan denga nilai yang diberikan guru dari kegiatan belajarnya. Siswa tentunya sangat terpikat dengan nilai-nilai ulangan atau raport yang tinggi. Nilai-nilai yang baik itu akan menjadikan motivasi yang kuat bagi para siswa untuk melakukan kegiatan belajar.

2. Hadiah Hadiah juga dapat dikatakan sebagai motivasi bagi para siswa. Baik hadiah tersebut berasal dari sekolah kepada siswa yang berprestasi, maupun dari orang tua atau keluarga.

3. Saingan/ Kompetisi Saingan atau kompetisi dapat digunakan sebagai alat motivasi untuk mendorong belajar siswa. Baik persaingan individu maupun persaingan kelompok dapat meningkatkan prestasi belajar siswa. Misalnya persaingan antara teman sebangku, jika si A mendapat nilai lebih baik dari pada si B, biasanya si B akan terdorong untuk dapat mengungguli si $A$.

4. Bekerja keras dengan mempertaruhkan harga diri merupakan salah satu bentuk motivasi. Seseorang akan berusaha keras untuk mencapai prestasi yang baik dengan menjaga harga dirinya. Para siswa akan belajar dengan keras untuk menjaga harga dirinya.

5. Memberi Ulangan Para siswa akan giat belajar jika mengetahui aka nada ulangan. Oleh karena itu, ulangan merupakan salah satu motivasi siswa untuk belajar. Jadi, guru harus terbuka memberitahukan kepada siswanya jika akan mengadakan ulangan.

6. Mengetahui Hasil Semakin mengetahui grafik hasi belajar, maka ada motivasi pada diri siswa untuk terus belajar, dengan suatu harapan hasilnya terus meningkat.

7. Pujian Dengan pujian yang tepat akan memupuk suasana menyenangkan dan mempertinggi semangat belajar serta sekaligus akan membangkitkan harga diri.

8. Hukuman Hukuman sebagai reinforcement negative tetapi kalau diberikan secara tepat dan bijak akan dapat menjadi alat motivasi. Jadi guru harus mampu menerapkan prinsipprinsip pemberian hukuman secara tepat.

9. Hasrat untuk Belajar Hasrat untuk belajar berarti pada diri siswa memang ada unsure kesengajaan dan maksud belajar, sehingga hasil belajar yang disertai tujuan belajar pasti hasilnya akan lebih baik. 
10. Minat Proses belajar akan berjalan lancar kalau disertai dengan minat terhadap pelajaran tersebut.

11. Tujuan yang Diakui Rumusan tujuan yang diakui dan diterima baik oleh siswa, akan menjadi motivasi yang penting. Sebab dengan memahami tujuan yang harus dicapai, akan diarasa sangat berguna dan menguntungkan, sehingga akan timbul motivasi untuk terus belajar.

\section{Pendidikan Jasmani \\ Pengertian Pendidikan Jasmani}

Pendidikan jasmani merupakan proses belajar mengajar melalui aktivitas jasmani untuk merangsang pertumbuhan dan perkembangan afektif, kognitif dan psikomotor secara menyeluruh, selaras, seimbang untuk menuju manusia Indonesia seutuhnya. Menurut Husdarta (2011:18), pendidikan jasmani adalah proses pendidikan melalui aktifitas jasmani, permainan atau olahraga yang terpilih untuk mencapai tujuan pendidikan. Sedangkan menurut Samsudin (2008) penjas merupakan proses pembelajaran melalui aktifitas jasmani yang bertujuan untuk menjadikan tubuh sehat dan bugar serta meningkatkan keterampilan motoric dan menumbuhkan sikap sportif dan kecerdasan emosi. Pendapat senada juga dikemukakan oleh Sukintaka (2001:5), pendidikan jasmani adalah proses interaksi antara siswa dengan lingkungan, melalui aktifitas jasmani yang dikelola secara sistematis untuk menuju manusia Indonesia seutuhnya. Hal tersebut ditegaskan lagi oleh Agus S (2004:9), bahwa pendidikan jasmani adalah suatu proses pembelajaran yang didesain untuk meningkatkan kebugaran jasmani, mengembangkan keterampilan motorik, pengetahuan dan perilaku hidup aktif, dan sikap sportif melalui kegiatan jasmani.

Pendidikan jasmani juga merupakan bagian dari pendidikan secara keseluruhan yang tidak dapat dipisahkan dan ikut membantu terwujudnya pendidikan secara umum.

\section{Tujuan Pendidikan Jasmani}

Secara garis besar tujuan pendidikan jasmani terdiri dari 4 ranah yaitu : (1) jasmani, (2) psikomotor, (3) afektif, (4) kognitif. (Sukintaka, 2001 : 16). Dari hal tersebut dapat diketahui bahwa secara umum pendidikan jasmani bermuara pada peralihan sosok pribadi yang adaptable denagan lingkungannya. Dari beberapa teori di atas dapat diambil kesimpulan bahwa pendidikan jasmani merupakan salah satu mata pelajaran yang penting, dilihat tujuannya, maka dalam pelaksanaan aktivitas fisik dan mental sama-sama diutamakan walaupun aktivitas fisik tampak lebih dominan. Dalam pelaksanaan pendidikan jasmani memiliki tujuan dan fungsi tidak hanya menumbuh kembangkan siswa dari satu aspek fisik saja, namun pendidikan jasmani juga menumbuhkan aspek-aspek yang lain seperti psikomotor, afektif, dan kognitif secara menyeluruh dan seimbang.

\section{Peranan Motivasi dalam Belajar}

Motivasi berkaitan dengan suatu tujuan. Sehubungan dengan hal tersebut Sardiman

A.M (2011: 85) menyebutkan ada tiga fungsi motivasi, yaitu:

1. Mendorong manusia untuk berbuat, yang akan menjadi penggerak dari setiap kegiatan yang akan dikerjakan.

2. Menentukan arah perbuatan, yaitu ke arah yang hendak dicapai.

3. Menyeleksi perbuatan, yaitu menentukan perbuatanperbuatan apa yang harus dikerjakan yang sesuai untuk mencapai tujuan, dengan mengesampingkan perbuatanperbuatan yang tidak bermanfaat bagi tujuan tersebut.

Motivasi pada dasarnya dapat membantu dalam memahami dan menjelaskan perilaku individu, termasuk perilaku individu yang sedang belajar. Ada bebarapa peranan penting dari motivasi dalam belajar dan pembelajaran (Hamzah B. Uno, 2011: 27) antara lain dalam:

1. Menentukan hal-hal yang dapat dijadikan penguat belajar

2. Memperjelas tujuan belajar yang hendak dicapai

3. Menentukan ragam kendali terhadap rangsangan belajar 


\section{Menentukan ketekunan dalam belajar.}

Dengan demikian peran motivasi dalam belajar yaitu sebagai pendorong siswa untuk berbuat ke arah tujuan yang hendak dicapai dengan menyeleksi perbuatan yang bermanfaat untuk mencapai tujuan tersebut, sehingga ketekunan dalam belajar akan terjadi.

Motivasi belajar siswa dalam mengikuti pelajaran pendidikan jasmani dipengaruhi oleh motivasi intrinsik dan motivasi ekstrinsik. Motivasi intrinsik adalah motivasi yang tercakup dalam situasi belajar yang bersumber dari kebutuhan dan tujuan-tujuan siswa sendiri. Motivasi ini sering disebut motivasi murni atau motivasi yang sebenarnya, yang timbul dari dalam diri siswa misalnya keinginan untuk mendapat ketrampilan tertentu, memperoleh informasi dan pemahaman, mengembangkan sikap untuk berhasil, menikmati kehidupan secara sadar memberikan sumbangan kepada kelompok, keinginan untuk diterima oleh orang lain. Motivasi ekstrinsik adalah motivasi yang disebabkan oleh faktorfaktor dari luar situasi belajar, seperti: angka, ijazah, tingkatan, hadiah, medali, pertentangan dan persaingan; yang bersifat negatif ialah ejekan (ridicule) dan hukuman. Motivasi ekstrinsik tetap diperlukan di sekolah, sebab pembelajaran di sekolah tidak semuanya menarik minat, atau sesuai dengan kebutuhan siswa. Ada kemungkinan siswa belum menyadari pentingnya bahan pelajaran yang disampaikan oleh guru. Dalam keadaan ini siswa bersangkutan perlu dimotivasi agar belajar. Guru berupaya membangkitkan motivasi belajar siswa sesuai dengan keadaan siswa itu sendiri (Oemar, 2005:112). Motivasi menentukan tingkat berhasil atau gagalnya kegiatan belajar siswa. Belajar tanpa motivasi sulit untuk mencapai keberhasilan secara optimal (Oemar, 2005:108). Oleh karena itu motivasi begitu berarti, dengan motivasi belajar siswa akan mencapai keberhasilan belajar secara optimal. Sehingga siswa kelas VIII termotivasi dalam mengikuti pembelajaran pendidikan jasmani di SMPN 2 Tembelang.

\section{METODE}

Rancangan penelitian merupakan pedoman dan langkah-langkah yang digunakan peneliti untuk melakukan penelitiannya. Penelitian ini berasal dari adanya permasalahan. Rancangan penelitian yang harus di buat secara sistematis dan logis, sehingga dapat di jadikan pedoman yang betul-betul dan mudah di pahami secara mendasar.

Pendekatan yang digunakan dalam penelitian ini adalah kuantitatif yang pada umumnya digunakan untuk mengumpulkan data yang luas dan banyak. Sugiyono (2013:12) menjelaskan bahwa pendekatan kuantitatif adalah pendekatan penelitian yang menggunakan angka-angka atau data yang dihitung serta dapat dianalisiskan secara sistematis dengan menggunakan statistic deskriptif. Penelitian ini dilakukan pada populasi besar maupun kecil yang bertujuan untuk mengumpulkan informasi berbentuk opini dari sejumlah besar siswa.

Desain penelitian merupakan gambaran singkat tentang semua proses yang diperluas dalam perencanaan dan pelaksanaan sebuah penelitian. Desain penelitian ini dapat di gambarkan secara sederhana sebagai berikut :

Variable-variabel yang terlibat dalam peneltian perlu didefinisikan untuk menghindari adanya kesalahn penafsiran dari pembaca. Definisi ini merupakan pengertian secara singkat sehingga masalah yang diteliti dapat dibatasi. Hal ini dimaksudkan untuk menghindari objek kajian yang terlalu luas dan mengaburkan variable sebenarnya yang diteliti.

1. Motivasi siswa yang dimaksud pada penelitian ini yaitu pendorong siswa untuk meningkatkan pembelajaran PJOK

2. Dalam pelaksanaan proses pembelajaran penjas untuk mengadakan perubahan, memperbaiki dan mempertahankan efektivitas belajar siswa secara permanen.

Sugiyono (2009:38) mendefinisikan bahwa "variable penelitian pada dasarnya adalah segala sesuatu yang berbentuk apa saja yang ditetapkan oleh peneliti untuk di pelajari sehingga diperoleh informasi tentang hal tersebut, kemudian ditarik kesimpulannya. Di dalam penelitian yang dimaksud variable penelitian adalah faktor-faktor yang berperan dalam suatu peristiwa yang akan mempengaruhi hasil penelitian. Adapun jenis variable dalam penelitian ini terbagi atas : 
1. Variabel bebas yaitu motivasi belajar

2. Variable terikat yaitu pembelajaran PJOK

Populasi dalam penelitian merupakan wilayah yang ingin diteliti oleh peneliti. Seperti menurut sugiyono (2011 : 80) " populasi dalah wilayah generalisasi yang terdiri atas objek/subjek yang mempunyai kualitas dan karakteristik tertentu yang ditetapkan oleh peneliti untuk dipelajari dan kemudian ditarik kesimpulannya." Pendapat diatas menjadi salah satu acuan bagi peneliti untuk menentukan populasi. Dalam penelitian ini peneliti menggunakan populasi penelitian yaitu siswa Smpn 2 Tembelang Jombang Tahun ajaran 2020/2021.

Sampel merupakan bagian dari populasi yang ingin diteliti oleh peneliti. Menurut Sugiyono (2011:81) "sampel adalah bagian dari jumlah dan karakteristik yang dimiliki oleh populasi tersebut." Sehingga sampel merupakan bagian dari populasi yang ada, sehingga untuk pengambilan sampel harus menggunakan cara tertentu yang didasarkan oleh pertimbangan yang ada. Dalam teknik pengambilan sampel menggunakan teknik Simple Random Sampling. Sugiyono (2001) menjelaskan bahwa: "Simple Random Sampling adalah metode pengambilan sampe yang simple (sederhana) sebab pengambilan sampel dari suatu populasi dilakukan secara acak tanpa memperhatikan strata yang ada dalam populasi itu." Adapun sampel yang akan diambil adalah kelas 8 dengan jumlah 128 siswa di SMP Negeri 2 Tembelang, dikarenakan pada masa peralihan atau masa transisi dari anak menuju dewasa pada masa ini begitu pesat mengalami pertumbuhan dan perkembangan baik itu fisik maupun mental dan ketidak seimbangan emosional dalam banyak hal sehingga dapat sangat berpengaruh pada motivasi belajar.

Menurut Notoatmodjo (2010) "Definisi instrumen penelitian adalah alat-alat yang akan digunakan untuk mengumpulkan data, instrumen penelitian ini dapat berupa kuesioner, formulir observasi, formulir-formulir lain yang berkaitan dengan pencatatan data dan sebagainya". Penelitian ini dilakukan dengan menggunakan instrumen yang belum berstandar, sehingga untuk menghindari hasil yang tidak sahih terlebih dahulu dilakukan uji coba terhadap instrument tersebut. Instrument untuk mengumpulkan data dalam penelitian ini berupa format quisioner/angket dengan kisi-kisi sebagai berikut:

Tabel 3.1 Kisi Kisi Instrument Penelitian Motivasi Belajar

\begin{tabular}{|c|c|c|c|c|}
\hline \multirow[t]{2}{*}{ Variabel } & \multirow[t]{2}{*}{ Faktor } & \multirow[t]{2}{*}{ Indikator } & \multicolumn{2}{|c|}{ Nomor Butir } \\
\hline & & & Positif & Negatif \\
\hline \multirow{9}{*}{$\begin{array}{c}\text { Motivasi } \\
\text { Belajar Dalam } \\
\text { Pembelajaran } \\
\text { Pjok Dimasa } \\
\text { Pandemic } \\
\text { Covid-19 }\end{array}$} & \multirow{5}{*}{ Intrinsik } & 1. kebutuhan & $1,2,3$ & 4 \\
\hline & & 2. Kesenangan & $6,7,8,11$ & $5,9,10$ \\
\hline & & 3. Pengetahuan & 12,15 & 13,14 \\
\hline & & 4. Perhatian & $17,18,19,22$ & $16,20,21$ \\
\hline & & 5. Prestasi & $23,24,25,26$ & 27 \\
\hline & \multirow{4}{*}{ Ekstrinsik } & 6. Teman & 28,29 & 30,31 \\
\hline & & $\begin{array}{l}\text { 7. } \\
\text { \&prasarana }\end{array}$ & $32,33,34,37$ & 35,36 \\
\hline & & 8. Guru & $38,39,40,41$ & $42,43,44$ \\
\hline & & 9. Orang tua & $45,46,47,48$ & 49,50 \\
\hline \multicolumn{4}{|c|}{ Jumlah Butir Soal } & 50 \\
\hline
\end{tabular}

Tabel 3.2 Kategori Jawaban Motivasi Belajar Siswa

\begin{tabular}{|c|c|c|c|}
\hline Pernyataan positif (+) & Skore & Pernyataan negatif (-) & Skore \\
\hline Sangat Setuju (SS) & 4 & Sangat Setuju (SS) & 1 \\
\hline
\end{tabular}




\begin{tabular}{|c|c|c|c|}
\hline Setuju (S) & 3 & Setuju (S) & 2 \\
\hline Tidak Setuju (TS) & 2 & Tidak Setuju (TS) & 3 \\
\hline $\begin{array}{c}\text { Sangat Tidak Setuju } \\
\text { (STS) }\end{array}$ & 1 & Sangat Tidak Setuju (STS) & 4 \\
\hline
\end{tabular}

Dalam mendeskripsikan tingkat motivasi belajar memiliki rentangan skore 1-4, dibuat interval kriteria motivasi belajar yang ditentukan dengan cara sebagai berikut:

$$
\begin{aligned}
& \text { Data maksimal }=\text { Skore tertinggi } \times \text { Jumlah Item }=4 \times 50=200 \\
&=4 / 4 \times 100 \%=100 \% \\
& \text { Data minimal }=\text { Skore terendah } \times \text { Jumlah Item }=1 \times 50=50 \\
&=1 / 4 \times 100 \%=25 \% \\
&=\text { Data maksimal }- \text { Data minimal }=200-50=150 \\
&=100 \%-25 \%=75 \% \\
& \text { Range } \\
& \text { Panjang kelas interval }=\text { Range }: \text { Panjang kelas }=150: 4=37,5 \\
&=75 \%: 4=18,75 \%=19 \%
\end{aligned}
$$

Tabel 3.3 Penilaian Motivasi Siswa

\begin{tabular}{|c|c|c|}
\hline Skore & Interval persentase & Kriteria \\
\hline $192-200$ & $96 \%-100 \%$ & Sangat tinggi \\
\hline $154-190$ & $77 \%-95 \%$ & Tinggi \\
\hline $126-152$ & $63 \%-76 \%$ & Sedang \\
\hline $88-124$ & $44 \%-62 \%$ & Rendah \\
\hline $50-86$ & $25 \%-43 \%$ & Sangat rendah \\
\hline
\end{tabular}

\section{Teknik Pengumpulan Data}

Metode pengumpulan data adalah teknik atau cara yang dilakukan untuk mengumpulkan data. Ada beberapa macam teknik pengumpulan data yang digunakan dalam suatu penelitian yaitu melalui angket, wawancara, pengamatan, tes dan doumentasi. Teknik pengumpulan data yang digunakan dalam penelitian ini adalah :

1. Observasi/survei

Survei adalah teknik pengumpulan data atau informasi pada populasi yang besar dengan menggunakan sampel yang relative lebih kecil serta kegiatan observasi dilakukan baik pada saat pra penelitian maupun pada saat penelitian yang sesungguhnya dengan mengamati proses belajar mengajar PJOK selama pandemi pada siswa SMP Negeri 2 Tembelang

2. Angket/kuisioner

Angket adalah metode yang digunakan untuk mengumpulkan data sehubungan dengan penelitian ini yakni menyangkut bakat dan minat berolahraga siswa, dengan mengajukan beberapa pertanyaan secara tertulis dan dijawab oleh responden/siswa sesuai petunjuk yang diberikan. Hal tersebut sejalan dengan apa yang dikemukakan oleh Suharsimi Arikunto (1992:124) bahwa " angket adalah sejumlah peryantaan tertulis yang digunakan untuk memperoleh informasi dari responden dalam arti laporan tentang pribadinya, atau hal-hal yang diketahui".

\section{Validitas dan Reliabilitas}

1. Validitas

Validitas berasal dari kata validity yang mempunyai arti sejauh mana ketepatan dan kecermatan suatu alat ukur dalam melakukan fungsi ukurnya (Azwar, 2008: 5-6) Validitas adalah suatu ukuran yang menunjukkan tingkat-tingkat kevalidan atau kesahihan sesuatu instrument. Suatu instrument yang valid atau shahih mempunyai validitas tinggi. Sebaliknya, instrument yang kurang valid berarti memiliki validitas rendah (Arikunto, 2010: 211)

Sedangkan untuk menguji validitas instrumen wawancara dan observasi menggunakan validitas konstruksi (construct validity). Validitas konstruksi (construct 
validity) yaitu validitas yang menggunakan pendapat ahli (jugment experts) dengan berkonsultasi dengan dosen ahli untuk menguji kevalidan instrumen yang digunakan.

Hasil perhitungan validitas pada 50 pernyataan kuesioner dengan menggunakan bantuan computer SPSS. Untuk nilai $r$ taraf kepercayaan $95 \%$ atau signifikansi $5 \%$ dapat dicari berdasarkan jumlah responden $(\mathrm{N})$ yang merujuk pada Tabel Nilai $\mathrm{R}$ Tabel Pearson Product Moment. Oleh karena $\mathrm{N}=75$ maka nilai $r$ tabel $=0,227$. Hasil Pearson Correlation pada tabel diatas diketahui bahwa 41 butir pernyataan memiliki nilai $r$ hitung $>r$ tabel sebesar 0,227 sehingga butir pernyataan dikatakan valid, dan terdapat 9 butir pernyataan memiliki $r$ hitung $<r$ tabel sehingga pernyataan dikatakan tidak valid. Hasil uji coba tersebut dapat dirincikan sebagai berikut :

Tabel 3.4 Butir Pernyataan Gugur Instrument Penelitian Motivasi

\begin{tabular}{|c|c|c|c|c|}
\hline \multirow[t]{2}{*}{ Variabel } & \multirow[t]{2}{*}{ Faktor } & \multirow[t]{2}{*}{ Indikator } & \multicolumn{2}{|c|}{ Nomor Butir } \\
\hline & & & Positif & Negatif \\
\hline \multirow{9}{*}{$\begin{array}{c}\text { Motivasi } \\
\text { Belajar Dalam } \\
\text { Pembelajaran } \\
\text { Pjok Dimasa } \\
\text { Pandemic } \\
\text { Covid-19 }\end{array}$} & \multirow{5}{*}{ Intrinsik } & 1. Kebutuhan & $1,2^{*}, 3$ & $4^{*}$ \\
\hline & & 2. Kesenangan & $6,7,8,11$ & $5,9,10^{*}$ \\
\hline & & 3. Pengetahuan & 12,15 & $13^{*}, 14$ \\
\hline & & 4. Perhatian & $17,18,19,22$ & $16,20,21$ \\
\hline & & 5. Prestasi & $23,24,25,26$ & $27^{*}$ \\
\hline & \multirow{4}{*}{ Ekstrinsik } & 6. Teman & 28,29 & 30,31 \\
\hline & & $\begin{array}{l}\text { 7. Sarana \& } \\
\text { prasarana }\end{array}$ & $32,33,34,37$ & $35,36^{*}$ \\
\hline & & 8. Guru & $38,39,40,41$ & $42,43,44^{*}$ \\
\hline & & 9. Orang tua & $45,46,47,48$ & $49^{*}, 50^{*}$ \\
\hline \multicolumn{4}{|c|}{ Jumlah Butir Soal } & 50 \\
\hline
\end{tabular}

Dengan demikian pernyataan variabel Motivasi Belajar menjadi 41 butir pernyataan, selanjutnya butir-butir pernyataan yang tidak valid atau gugur tersebut tidak disertakan dalam pengambilan data penelitian karena sisa pernyataan yang ada masih dapat mewakili masing-masing indikator dari variabel tersebut.

Reliabilitas

Hasil pengukuran dapat dipercaya hanya apabila dalam beberapa kali pelaksanaan pengukuran terhadap kelompok subjek yang sama diperoleh hasil yang relative sama, selama aspek yang diukur dalam diri subjek memang belum berubah (Azwar, 2008: 4). Hasil uji reliabilitas menggunakan rumus Alpha Cronbach yang dapat dilihat pada tabel berikut:

Tabel 3.5 uji reliabilitas

\begin{tabular}{|c|c|l|}
\hline Cronbach Alpha & $\mathbf{N}$ & Kesimpulan \\
\hline 0,831 & 50 & Reliabel \\
\hline
\end{tabular}

Dari tabel diatas berdasarkan hasil pengolahan data menggunakan SPSS, dapat diketahui bahwa semua pernyataan yang ada pada setiap variabel tersebut reliabel. Hal tersebut ditunjukan dengan keseluruhan nilai Cronbach Alpha dari 50 butir pernyataan bernilai > 0,6. Hal ini menunjukkan bahwa setiap pernyataan yang digunakan sebagai alat ukur adalah reliabel dan dapat digunakan untuk penelitian selanjutnya.

\section{Teknik Analisis Data}

Teknik analisa data merupakan suatu langkah yang paling menentukan dari suatu penelitian, karena analisa data berfungsi untuk menyimpulkan hasil penelitian. Analisis data dapat dilakukan melalui tahap Penelitian berikut :

a. Perencanaan

Pada tahap ini kegiatan yang dilakukan adalah sebagai berikut:

1) Peneliti merancang kelas yang akan dijadikan sampel. 
2) Peneliti membuat instrumen-instrumen penelitian yang akan digunakan untuk penelitian.

b. Pelaksanaan Pada tahap ini kegiatan yang dilakukan adalah sebagai berikut:

1) Peneliti melaksanakan pembelajaran pada sampel penelitian.

2) Peneliti menguji coba, menganalisis dan menetapkan instrumen penelitian.

Evaluasi Pada tahap ini, peneliti menganalisis dan mengolah data yang telah dikumpulkan dengan metode yang telah ditentukan dengan cara :

a) Memberikan Skor nilai dari masing-masing respon jawaban yang telah diberikan oleh tiap-tiap responden

b) Memindahkan seluruh hasil penyekoran ke dalam bentuk tabulasi data dalam komputer

c) Merekap jumlah skor dari masing-masing sub variable dan skor secara keseluruhan

d) Mencocokkan hasil penjumlahan masing-masing sub variabel dan keseluruhan ke dalam masing-masing tabel kriteria yang telah dibuat

Menghitung skor rata-rata dari masing-masing sub variabel dan skor keseluruhan kemudian dirubah ke dalam bentuk persentase, adapun rumus dari deskriptif persentase adalah, sebagai berikut:

Keterangan :

$\%=$ nilai persentase/hasil $\quad \%=\frac{n}{N} \times 100 \%$
$\mathrm{n}=$ jumlah skor yang diperoleh
$\mathrm{N}=$ jumlah skor yang diharapkan

Tabel 3.6 Penafsiran Kategori \%

\begin{tabular}{|c|c|}
\hline Interval Persentase & Kategori \\
\hline $96 \% \leq \% \leq 100 \%$ & Sangat tinggi \\
\hline $77 \% \leq \% \leq 95 \%$ & Tinggi \\
\hline $63 \% \leq \% \leq 76 \%$ & Sedang \\
\hline $44 \% \leq \% \leq 62 \%$ & Rendah \\
\hline $25 \% \leq \% \leq 43 \%$ & Sangat rendah \\
\hline
\end{tabular}

c. Penyusunan Laporan Pada tahap ini, kegiatan yang dilakukan adalah menyusun dan melaporkan hasil-hasil penelitian.

\section{HASIL DAN PEMBAHASAN}

\section{Hasil Penelitian}

Penelitian ini merupakan jenis penelitian kuantitatif dengan menggunakan metode survei, dengan begitu penelitian ini tidak memerlukan perumusan hipotesis. Dengan telah terlaksananya penelitian ini maka hasil penelitian berdasarkan dengan tujuan penelitian ini sebagaimana telah dijelaskan dalam bab yang sebelumnya, yakni untuk mengetahui seberapa besar motivasi siswa dalam pembelajaran Pjok dimasa pandemi COVID-19 di SMPN 2 Tembelang Jombang.

Dalam penelitian ini menggunakan subyek siswa kelas 8 di SMPN 2 Tembelang Jombang dengan jumlah sebanyak 128 siswa. Penelitian ini dilakukan pada tanggal 30 agustus 2020 sampai dengan 10 september 2020, selama kurang lebih 12 hari penelitian ini dilakukan secara online dengan cara penyebaran angket dalam bentuk Google Formulir dengan data berupa link dan disebarkan kepada siswa melalui aplikasi sosial media yang paling banyak digunakan untuk berkomunikasi yakni WhatsApp.

Berdasarkan dengan data yang diperoleh dari 99 siswa sebagai sampel, maka memperoleh hasil keseluruhan pengisian angket motivasi belajar siswa, sesuai dengan rumusan masalah dapat dilihat sebagai berikut:

Pada bagian ini akan dikemukakan pengujian hipotesis berdasarkan hasil data yang diperoleh dari hasil angket yang telah di isi oleh sampel sebagai berikut : 
Tabel. 4.1. Hasil Analisis Skor Nilai Siswa

\begin{tabular}{|c|c|c|c|c|}
\hline NO & SISWA & SKOR & NILAI & KRITERIA \\
\hline 1 & Siswa 1 & 114 & 69 & Tinggi \\
\hline 2 & Siswa 2 & 124 & 75 & Tinggi \\
\hline 3 & Siswa 3 & 135 & 82 & Sangat Tinggi \\
\hline 4 & Siswa 4 & 134 & 81 & Tinggi \\
\hline 5 & Siswa 5 & 116 & 70 & Tinggi \\
\hline 6 & Siswa 6 & 124 & 75 & Tinggi \\
\hline 7 & Siswa 7 & 114 & 69 & Tinggi \\
\hline 8 & Siswa 8 & 116 & 70 & Tinggi \\
\hline 9 & Siswa 9 & 113 & 68 & Tinggi \\
\hline 10 & Siswa 10 & 120 & 73 & Tinggi \\
\hline 11 & Siswa 11 & 122 & 74 & Tinggi \\
\hline 12 & Siswa 12 & 119 & 72 & Tinggi \\
\hline 13 & Siswa 13 & 112 & 68 & Tinggi \\
\hline 14 & Siswa 14 & 116 & 70 & Tinggi \\
\hline 15 & Siswa 15 & 115 & 70 & Tinggi \\
\hline 16 & Siswa 16 & 121 & 73 & Tinggi \\
\hline 17 & Siswa 17 & 113 & 68 & Tinggi \\
\hline 18 & Siswa 18 & 155 & 94 & Sangat Tinggi \\
\hline 19 & Siswa 19 & 114 & 69 & Tinggi \\
\hline 20 & Siswa 20 & 123 & 75 & Tinggi \\
\hline 21 & Siswa 21 & 111 & 67 & Tinggi \\
\hline 22 & Siswa 22 & 112 & 68 & Tinggi \\
\hline 23 & Siswa 23 & 131 & 79 & Tinggi \\
\hline 24 & Siswa 24 & 130 & 79 & Tinggi \\
\hline 25 & Siswa 25 & 113 & 68 & Tinggi \\
\hline 26 & Siswa 26 & 117 & 71 & Tinggi \\
\hline 27 & Siswa 27 & 122 & 74 & Tinggi \\
\hline 28 & Siswa 28 & 113 & 68 & Tinggi \\
\hline 29 & Siswa 29 & 120 & 73 & Tinggi \\
\hline 30 & Siswa 30 & 119 & 72 & Tinggi \\
\hline 31 & Siswa 31 & 124 & 75 & Tinggi \\
\hline 32 & Siswa 32 & 116 & 70 & Tinggi \\
\hline 33 & Siswa 33 & 116 & 70 & Tinggi \\
\hline 34 & Siswa 34 & 120 & 73 & Tinggi \\
\hline 35 & Siswa 35 & 113 & 68 & Tinggi \\
\hline 36 & Siswa 36 & 115 & 70 & Tinggi \\
\hline 37 & Siswa 37 & 103 & 62 & Rendah \\
\hline 38 & Siswa 38 & 120 & 73 & Tinggi \\
\hline 39 & Siswa 39 & 120 & 73 & Tinggi \\
\hline 40 & Siswa 40 & 86 & 52 & Rendah \\
\hline 41 & Siswa 41 & 130 & 79 & Tinggi \\
\hline 42 & Siswa 42 & 120 & 73 & Tinggi \\
\hline 43 & Siswa 43 & 158 & 96 & Sangat Tinggi \\
\hline 44 & Siswa 44 & 116 & 70 & Tinggi \\
\hline 45 & Siswa 45 & 116 & 70 & Tinggi \\
\hline 46 & Siswa 46 & 123 & 75 & Tinggi \\
\hline 47 & Siswa 47 & 123 & 75 & Tinggi \\
\hline 48 & Siswa 48 & 127 & 69 & Tinggi \\
\hline 49 & Siswa 49 & 110 & 67 & Tinggi \\
\hline
\end{tabular}




\begin{tabular}{|c|c|c|c|c|}
\hline NO & SISWA & SKOR & NILAI & KRITERIA \\
\hline 50 & Siswa 50 & 108 & 65 & Tinggi \\
\hline 51 & Siswa 51 & 109 & 66 & Tinggi \\
\hline 52 & Siswa 52 & 109 & 66 & Tinggi \\
\hline 53 & Siswa 53 & 120 & 73 & Tinggi \\
\hline 54 & Siswa 54 & 113 & 68 & Tinggi \\
\hline 55 & Siswa 55 & 103 & 62 & Rendah \\
\hline 56 & Siswa 56 & 119 & 72 & Tinggi \\
\hline 57 & Siswa 57 & 118 & 71 & Tinggi \\
\hline 58 & Siswa 58 & 120 & 73 & Tinggi \\
\hline 59 & Siswa 59 & 113 & 68 & Tinggi \\
\hline 60 & Siswa 60 & 132 & 86 & Sangat Tinggi \\
\hline 61 & Siswa 61 & 129 & 78 & Tingqi \\
\hline 62 & Siswa 62 & 108 & 65 & Tinggi \\
\hline 63 & Siswa 63 & 122 & 74 & Tinggi \\
\hline 64 & Siswa 64 & 117 & 71 & Tinggi \\
\hline 65 & Siswa 65 & 130 & 79 & Tinggi \\
\hline 66 & Siswa 66 & 115 & 70 & Tinggi \\
\hline 67 & Siswa 67 & 117 & 71 & Tinggi \\
\hline 68 & Siswa 68 & 124 & 75 & Tinggi \\
\hline 69 & Siswa 69 & 123 & 75 & Tinggi \\
\hline 70 & Siswa 70 & 140 & 85 & Sangat Tinggi \\
\hline 71 & Siswa 71 & 149 & 90 & Sangat Tinggi \\
\hline 72 & Siswa 72 & 126 & 76 & Tinggi \\
\hline 73 & Siswa 73 & 132 & 86 & Sangat Tinggi \\
\hline 74 & Siswa 74 & 121 & 73 & Tinggi \\
\hline 75 & Siswa 75 & 121 & 73 & Tinggi \\
\hline 76 & Siswa 76 & 129 & 78 & Tinggi \\
\hline 77 & Siswa 77 & 124 & 75 & Tinggi \\
\hline 78 & Siswa 78 & 125 & 76 & Tinggi \\
\hline 79 & Siswa 79 & 124 & 75 & Tinggi \\
\hline 80 & Siswa 80 & 121 & 73 & Tinggi \\
\hline 81 & Siswa 81 & 121 & 73 & Tinggi \\
\hline 82 & Siswa 82 & 122 & 74 & Tinggi \\
\hline 83 & Siswa 83 & 152 & 92 & Sangat Tinggi \\
\hline 84 & Siswa 84 & 118 & 71 & Tinggi \\
\hline 85 & Siswa 85 & 124 & 75 & Tinggi \\
\hline 86 & Siswa 86 & 119 & 72 & Tinggi \\
\hline 87 & Siswa 87 & 127 & 69 & Tinggi \\
\hline 88 & Siswa 88 & 147 & 89 & Sangat Tinggi \\
\hline 89 & Siswa 89 & 121 & 73 & Tinggi \\
\hline 90 & Siswa 90 & 119 & 72 & Tinggi \\
\hline 91 & Siswa 91 & 118 & 71 & Tinggi \\
\hline 92 & Siswa 92 & 148 & 90 & Sangat Tinggi \\
\hline 93 & Siswa 93 & 152 & 92 & Sangat Tinggi \\
\hline 94 & Siswa 94 & 123 & 75 & Tinggi \\
\hline 95 & Siswa 95 & 122 & 74 & Tinggi \\
\hline 96 & Siswa 96 & 121 & 73 & Tinggi \\
\hline 97 & Siswa 97 & 111 & 67 & Tingqi \\
\hline 98 & Siswa 98 & 125 & 76 & Tinggi \\
\hline 99 & Siswa 99 & 124 & 75 & Tinggi \\
\hline \multicolumn{2}{|c|}{ Jumlah } & 12039 & & \\
\hline
\end{tabular}




\begin{tabular}{|l|l|l|l|l|}
\hline NO & SISWA & SKOR & NILAI & KRITERIA \\
\hline Nilai Tertinggi & & 96 & \\
\hline Nilai Terendah & & $\mathbf{5 2}$ & \\
\hline Rata-Rata & & $\mathbf{7 3}$ & Tinggi \\
\hline
\end{tabular}

Berikut ini adalah hasil analisis skor nilai motivasi siswa dalam pembelajaran PJOK dimasa pandemi Covid-19 di Smp Negeri 2 Tembelang dengan total skor 12039 nilai tertinggi 86 nilai terendah 52 dan rata-rata 73 dengan kategori Tinggi.

Tabel 4.2 Analisis Deskriptif

\section{Statistics}

\begin{tabular}{llr} 
VAR00001 & & \\
$\mathrm{N}$ & Valid & 99 \\
\cline { 2 - 3 } & Missing & 0 \\
\hline Mean & & 121,61 \\
\hline Median & 120,00 \\
Mode & $120^{\mathrm{a}}$ \\
\hline Std. Deviation & 11,170 \\
\hline Variance & 124,772 \\
\hline Range & 72 \\
\hline Minimum & 86 \\
\hline Maximum & 158 \\
\hline Sum & 12039 \\
\hline
\end{tabular}

a. Multiple modes exist. The smallest value is shown

Berdasarkan tabel statistik deskriptif diatas, dapat diketahui bahwa, nilai Mean 121,61, Median 120,00, Mode 120, Standar Deviasi 11,170, Varian 124,772, Range (rentang) 72, maximum 158 dan minimum 86 . Dengan total skor pada setiap responden (99) dan setiap pernyataan (41) adalah 12039.

\section{Pembahasan}

Penelitian ini bertujuan untuk mengetahui motivasi siswa dalam pembelajaran PJOK di masa pandemic COVID-19 pada siswa Smp Negeri 2 Tembelang Tahun Ajaran 2020/2021 menggunakan kuesioner online yang dibagikan kepada siswa. Hasil penelitian menunjukkan bahwa pada masa pandemi COVID-19 ini semua siswa tetap melaksanakan pembelajaran PJOK. Secara keseluruhan pelaksanaan pembelajaran PJOK menggunakan media daring zoom dan aplikasi WhatsApp. dengan menyesuaikan materi sesuai kondisi dan arahan dari dinas pendidikan. Hal ini disesuaikan dengan Surat Edaran nomor 4 tahun 2020 tentang Pelaksanaan Pendidikan dalam Masa Darurat COVID-19 yang menyatakan pemerintah memberlakukan kegiatan belajar secara daring dalam rangka pencegahan penyebaran COVID-19 (Kemendikbud,2020).

Maka dapat disimpulkan bahwa motivasi siswa dalam pembelajaran PJOK di masa pandemi COVID-19 pada siswa Smp Negeri 2 Tembelang Tahun Ajaran 2020/2021 tetap tinggi walaupun dengan metode pembelajaran daring. Diperoleh 3 kategori hasil Analisis dari penelitian ini yang pertama kategori sangat tinggi memperoleh Nilai 96 kategori tinggi dengan memperoleh Nilai rata-rata 73 dan kategori rendah memproleh Nilai 52.

Dari Nilai tersebut dijelaskan pembelajaran tetap dilaksanaan meskipun terdapat pandemi COVID-19. Kesiapan siswa dalam menghadapi pembelajaran yang modern sangat diperlukan, serta siswa juga dituntut untuk lebih terbuka terhadap teknologi yang semakin canggih dan terus berkembang. Pembelajaran Daring dirasa lebih maju dan sangat dibutuhkan pada masa pandemi COVID-19 seperti ini, karena siswa dituntut tidak saling bertatap muka secara langsung dalam suatu proses pembelajaran. Namun, tidak semua siswa dapat melakukan pembelajaran secara mandiri, kapanpun dan dimanapun. Dalam proses pembelajaran PJOK melalui daring yang dilaksanakan dari rumah ini mampu untuk meningkatkan keterampilan motorik dan nilai-nilai fungsional yang mencakup aspek kognitif, 
afektif, Guru tidak hanya memberi materi yang banyak dan monoton untuk siswa sehingga membuat siswa menjadi bosan, jenuh dan semakin stres tetapi dalam pembelajaran PJOK ini tugas guru juga meningkatkan tarap kebugaran jasmani pada siswa dengan memberikan beberapa pelaksanaan tugas berupa membuat video praktik.

Namun di sisi lain pembelajaran di rumah pastinya memiliki tantangan dan kendala tersendiri bagi siswa hal itu ditunjukkan oleh nilai hasil prosentase yang lebih banyak pada kategori tinggi di setiap indikator yang mempengaruhi motivasi dalam pembelajaran PJOK di masa pandemi COVID-19 pada siswa Smp Negeri 2 Tembelang. Kurangnya rasa suka, perhatian, kesukaan, dan keterlibatan siswa dalam pembelajaran daring dapat mempengaruhi motivasi siswa mengikuti pembelajaran dengan baik. Faktor lain dapat disebabkan oleh media pembelajaran yang tidak semua siswa memiliki media pembelajaran yang berupa alat elektronika (komputer, laptop, HP android), serta fasilitas media pembelajaran berupa alat-alat olahraga yang kurang memadai saat berada dirumah. Keterbatasan ekonomi dalam pembelian kuota/paket serta kendala pada sinyal atau jaringan sehingga siswa sering mengalami kesulitan dalam proses pembelajaran berlangsung. Dan kendala selanjutnya adalah guru mengalami kesusahan dalam penilaian pembelajaran PJOK selama daring.

\section{SIMPULAN}

Berdasarkan hasil analisa data dari tiap indikator dapat ditarik kesimpulan dengan keseluruhan data yang diperoleh menunjukkan motivasi siswa dalam pembelajaran PJOK dimasa pandemi COVID-19 dengan hasil skor sebanyak 12039, sehingga motivasi siswa dalam pembelajaran PJOK dimasa pandemi COVID-19 pada siswa Smpn 2 Tembelang Tahun Ajaran 2020/2021 adalah tinggi dengan jumlah rata-rata 73.

\section{UCAPAN TERIMA KASIH}

Ucapan terima kasih ditujukan kepada Sekolah Tinggi Keguruan dan Ilmu Pendidikan Persatuan Guru Republik Indonesia Jombang yang telah memberikan dukungan meneliti dan melaksanakan penelitian ini dan ucapan terima kasih ditujukan kepada SMPN 2 Tembelang yang telah berkontribusi mendukung pelaksanaan penelitian di institusi.

\section{DAFTAR PUSTAKA}

A.M, Sardiman. 1990. Interaksi dan Motivasi Belajar Mengajar, Jakarta : C.V. Rajawali.

A.M. Sardiman. 2011. Interaksi dan Motivasi Belajar Mengajar. PT Rajagrafindo: Jakarta

Agus S.Suryobroto. (2004). Sarana dan Prasarana Pendidikan Jasmani. Yogyakarta: Fakultas IImu Keolahragaan UNY.

Amaludin, A. (2013). Survei Motivasi Belajar Siswa Dalam Mengikuti Pendidikan Jasmani Melalui Aktivitas Permainan Kecil Di Smplb Manunggalslawi Kab. Tegal Tahun 2012. Active: Journal of Physical Education, Sport, Health and Recreation, 2(5).

B. Uno, Hamzah. 2008. Teori Motivasi dan Pengukurannya, Jakarta : Bumi Aksara.

D Padli , Rahmiaty. (2018). Survei Motivasi Belajar Siswa Terhadap Mata Pelajaran Pendidikan Jasmani Di Kelas Xi IPA SMA Negeri 3 Enrekang Kabupaten Enrekang. Makassar

Hasan, M. lqbal, Pokok-pokok Materi Metodologi Penelitian dan Aplikasinya, Ghalia Indonesia, Bogor, 2002.

Husdarta, H.J.S. 2011. Manajemen Pendidikan Jasmani. Bandung: Alfabeta

Matondang, Z. (2009). Validitas dan reliabilitas suatu instrumen penelitian. Jurnal Tabularasa, 6(1), 87-97.

Nazhar. (2004). Peranan Motivasi dan Kemampuan Awal dalam Kegiatan Pembelajaran. Jakarta:

Notoatmodjo. 2010. Promosi kesehatan dan prilaku kesehatan. Jakarta: Rineka Cipta

Oemar. 2005. Proses Belajar Mengajar. Jakarta. Bumi Aksara. 
Pujadi, A. (2007). Faktor-faktor yang mempengaruhi motivasi belajar mahasiswa: studi kasus pada fakultas ekonomi universitas bunda mulia. Business Management Journal, 3(2).

Ridwan. 2013. Dasar-Dasar Statistika. Bandung : Alfabeta.

Sadirman. (2004). Interaksi dan Motivasi Belajar. Jakarta: PT Rineka Cipta.

Samsudin (2008). Pembelajaran Pendidikan Jasmani Olah Raga dan Kesehatan SMA/ MA. PT. Fajar Interpratama. Jakarta.

Sanjaya, Wina. (2010). Kurikulum dan pembelajaran, Teori dan praktek Pengembangan Kurikulum KTSP. Jakarta: Kencana.

Sugihartono, dkk (2007) psikologi pendidikan, Yogyakarta : UNY press

Sugiyono 2001, Metode Penelitian Administrasi, Penerbit Alfabeta Bandung

Sugiyono. (2009). Metode Penelitian Kualitatif Kuantitatif dan R\&D. Bandung : Alfabeta

Sugiyono. 2011. Metode Penelitian Kuantitatif, Kualitatif dan R\&D. Bandung: Afabeta

Sugiyono.2013. Metode Penelitian Pendidikan. Pebdekatan kuantitatif/ kualitatif, dan R \& D, cetakan ke-16, Bandung : Alfabeta

Suharsimi, Arikunto. 2002. Metodologi Penelitian. Jakarta: Penerbit PT. Rineka Cipta.

Sukintaka. (2001). Teori Pendidikan Jasmani [Physical Education Theory]. Solo: Esa Grafika Apriyanto.

Thorikunnafi , Muhammad Kholik. (2018). Survei Motivasi Belajar Terhadap Pembelajaran Pendidikan Jasmani Olahraga Dan Kesehatan Pada Siswa Kelas VII SMPN Kediri Tahun Ajaran 2017/2018. Kediri : Universitas Nusantara PGRI Kediri

Umar, H. 2000, Metode Penelitian. Jakarta : Salemba Empat.

Uno B. Hamzah, 2011. Teori Motivasi dan Pengukurannya Analisis di Bidang Pendidikan, Jakarta: PT. Bumi Aksara

Winarsih, Varia. (2009) Psikologi Pendidikan. Medan: Latansa Pers.

Winkel, WS. 1983. Psikologi Pendidikan dan Evaluasi Belajar (terjemahan). Jakarta : PT. Gramedia. 